\title{
Methanolic Extract of Rhinella marina Poison: Chemical Composition, Antioxidant and Immunomodulatory Activities
}

\author{
Sheila R. N. Pelissari, ${ }^{a}$ Valéria D. G. Sinhorin, ${ }^{\circledR a}$ Lindsey Castoldi, ${ }^{b}$ \\ Leonardo G. de Vasconcelos, ${ }^{c}$ Domingos J. Rodrigues, ${ }^{a}$ Eloana B. S. Ribeiro, ${ }^{d}$ \\ Jacqueline Kerkhoff ${ }^{\odot d}$ and Adilson P. Sinhorin ${ }^{\circledR *, a}$ \\ ${ }^{a}$ Laboratórios Integrados de Pesquisa em Química (LIPEQ), \\ Programa de Pós-Graduação em Ciências Ambientais, Instituto de Ciências Naturais, Humanas e Sociais, \\ Universidade Federal de Mato Grosso (UFMT), Campus de Sinop, Av. Alexandre Ferronato, 1200, \\ Bairro Setor Industrial, 78557-267 Sinop-MT, Brazil \\ ${ }^{b}$ Núcleo de Pesquisa e Apoio Didático em Saúde (NUPADS), Instituto de Ciências da Saúde, \\ Universidade Federal de Mato Grosso, Campus de Sinop, Av. Alexandre Ferronato, 1200, \\ Bairro Setor Industrial, 78557-267 Sinop-MT, Brazil \\ 'Departamento de Química, Instituto de Ciência Exatas e da Terra, \\ Universidade Federal de Mato Grosso (UFMT), Av. Fernando Corrêa da Costa, 2367, \\ Bairro Boa Esperança, 78060-900 Cuiabá-MT, Brazil \\ ${ }^{d}$ Programa de Pós-Graduação Rede de Biodiversidade e Biotecnologia da Amazônia Legal (PPG) \\ BIONORTE, Coordenação Geral do Doutorado em Biodiversidade e Biotecnologia, \\ Universidade Estadual do Maranhão, Cidade Universitária Paulo VI, Prédio da Veterinária, \\ Av. Lourenço Vieira da Silva, 1000, 65055-310 São Luis-MA, Brazil
}

\begin{abstract}
This study investigated the chemical composition, immunomodulatory and antioxidant activities, and histopathological analysis of mice tissues treated with methanolic extract from $R$. marina poison. Marinobufagin, telecinobufagin and bufalin were identified in the chemical profile. The biochemical results demonstrated an effect between doses in the period of 7 days, an immunomodulatory effect was observed regarding the production capacity of interleukin (IL)-12p70 and tumor necrosis factor (TNF)- $\alpha$ at 7 and 30 days, respectively. The lower dose suggests better bioactivity to the treated animal than the higher dose. Histopathological analyses of the lung, heart, kidney and liver showed tissue damage in all organs, mainly in the lung, and were proportional to the dose and the treatment period. We observed that the treatment modulated cytokine production, and therefore this effect may be related to the tissue damage observed. This study demonstrates a positive effect in the antioxidant and immune system, indicating that the molecules found in the extract have biotechnological potential.
\end{abstract}

Keywords: Rhinella marina, oxidative stress, immunomodulation, venon, parotoid gland, toad

\section{Introduction}

Brazil has the greatest biodiversity and the largest equatorial and tropical humid forest on the planet. ${ }^{1,2}$ In this context, we cite the Brazilian Amazon which has aroused the interest of countries and international institutions for centuries for containing great biodiversity, in addition to providing important systemic services and as a climate regulator. ${ }^{3,4}$

*e-mail: sinhorin.adilson@gmail.com
The Rhinella marina (Linnaeus, 1758) toad (R. marina) Figure 1, the main genus within the Bufonidae (true toad) family, and formerly known as Bufo marinus, can be found from the extreme south of Texas (USA), to the center of South America in the Brazilian Amazon. ${ }^{5}$ It is known by the names cururu toad "sapo cururu", giant toad "sapo gigante" in Brazil, and as the "cane toad" in Australia. ${ }^{6,7}$ Some species produce toxins which are rich in bioactive compounds and act in both maintaining skin homeostasis and in defense mechanisms against predators. ${ }^{5,6,8-11}$ These toxins are rich in proteins, peptides, and biogenic amines, 
and are also important steroidal buffaloids and alkaloids. ${ }^{8,11}$ Natural products play a very important role in the drug discovery and development processes. ${ }^{12}$ Thus, scientific research seeks to intensify studies on bufadienolides for having antimicrobial, ${ }^{13}$ antiproliferative, ${ }^{14,15}$ cytotoxic and/or antitumor ${ }^{12}$ and antiplasmodial activities. ${ }^{16}$

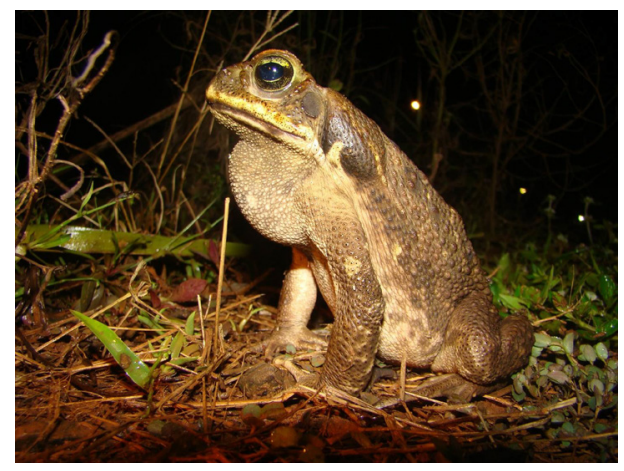

Figure 1. $R$. marina toad.

There is currently an increase in studies with compounds which have antioxidant activities due to their potential in treating diseases such as cancer, degenerative and cardiovascular diseases and brain disorders such as Alzheimer's and Parkinson's. ${ }^{17}$ The balance between producing free radicals and the neutralization carried out by the antioxidant system enables a cell protection role against oxidative stress. ${ }^{18-20}$ The imbalance between these two factors leads to oxidative stress, which is responsible for various damage to the organism such as various diseases and premature aging, among others. ${ }^{21-23}$ The antioxidant system is divided into enzymatic and non-enzymatic which can act by different mechanisms, either preventing the production of free radicals or non-radical species, or repairing damaged biological structures. ${ }^{24}$

The immune system also produces and uses free radical species as an effector mechanism to eliminate microorganisms. ${ }^{24}$ The immune system is divided between innate and adaptive response, and is regulated by the cells involved in these systems. ${ }^{25}$ The innate immune system responds quickly to stimuli in a non-specific manner and is composed of neutrophils, eosinophils, basophils, monocytes, macrophages and natural killer cells (NK), and the adaptive immune response is the second line of defense composed of T and B lymphocytes. ${ }^{25}$ Macrophages produce reactive oxygen species such as superoxide anion $\left(\mathrm{O}_{2}^{-\cdot}\right)$, hydroxyl radical $\left(\mathrm{OH}^{*}\right)$ and hydrogen peroxide $\left(\mathrm{H}_{2} \mathrm{O}_{2}\right)$, and reactive nitrogen such as oxide nitric (NO') to prevent the spread of pathogens. ${ }^{24}$ The immune system cells secrete a variety of proteins known as cytokines which have different structures and functions to regulate and coordinate the innate and adaptive immunity activities. ${ }^{26}$
However, the immune response is not always efficient to eliminate the infection, often being responsible for the morbidity associated with the disease, thereby requiring immunomodulation through substances capable of stimulating or inhibiting some immune cell functions. ${ }^{27}$

There are many studies ${ }^{28,29}$ which have evaluated the antioxidant and immunomodulatory potential of plants. However, studies involving extracts obtained from the cutaneous secretion of true toads (Bufonidae) are still very scarce. Knowing the compounds present in the poison is extremely important, as well as understanding the possible synergistic action between true toads. ${ }^{14}$ New diseases such as cancer arise every day which challenge medicine and the pharmaceutical industry, and despite constantly introducing new drugs in the therapeutic arsenal of cancer, several tumors still do not have adequate treatment. ${ }^{30}$ Combining natural products with bioprospecting offers the potential to discover new structures which can result in effective agents against a variety of human diseases. ${ }^{12}$ In addition, it is important to highlight that this study can increase scientific knowledge of Amazonian anurofauna which is still little known, and threatened by changes in habitat and climate changes which may influence a population decline in amphibians since they are sensitive to these changes. ${ }^{31}$

Thus, this work aimed to study the chemical composition and carry out studies on the immunomodulatory and antioxidant activities of methanolic extract from $R$. marina toad poison.

\section{Experimental}

\section{Poison collection and extract preparation}

The adult animals (males and females) were captured and identified by D. J. Rodrigues (IBAMA, SISBIO: 30034-1). The collection took place in the municipality

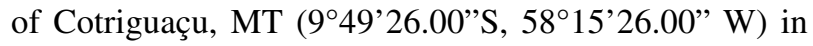
November and December 2016. The toad poison was obtained through manual compression of the parotoid glands. The poison was dried, crushed and extracted by maceration with methanol 99\% using an ultrasonic bath (Unique, Indaiatuba, São Paulo, Brazil) for two hours in order to obtain the methanolic extract. Next, it was filtered through filter paper (Unifil), and the poison was macerated twice more under the same conditions. Finally, the extracts were grouped and the solvent was rotary evaporated (IKA, Staufen, Germany) at $40{ }^{\circ} \mathrm{C}$ and kept under vacuum in a desiccator at room temperature for $48 \mathrm{~h}$. The obtained methanolic extract was stored at $4{ }^{\circ} \mathrm{C}$. The experimental conditions are in accordance with previous work done by this research group. ${ }^{32}$ 
Analysis by liquid chromatography with detection by ultraviolet spectroscopy and mass spectrometry

The analyzes by liquid chromatography were performed in an ultra-high pressure liquid chromatography system with diode-array detection (DAD) and mass spectometry (MS) detection (UHPLC-DAD-micrOTOF), equipped with: binary system (Shimadzu LC-20AD); automatic injection system (Shimadzu SIL-20A HT); column oven (Shimadzu CTO-20A); communication control module (Shimadzu CBM-20A), diode array detector (Shimadzu SPD-M20A), mass spectrometer (Bruker micrOTOF-QIII) and data acquisition and treatment software (Compass of Control, version 3.4; Compass Data Analysis, version 4.2; Compass HyStar, version 3.2).

Chromatographic conditions: injection volume $1 \mu \mathrm{L}$, chromatographic column Kromasil 100-5-C18 column, $250 \times 4.6 \mathrm{~mm}$, particle size $5 \mu \mathrm{m}$, SN E66320, C18 RP, pre-column Kromasil Guard 100-5-C18, $4.6 \times 10 \mathrm{~mm}$, particle size $5 \mu \mathrm{m}$. Chromatographic method: mobile phase solvent A: $0.5 \%$ formic acid solution, solvent $\mathrm{B}$ : acetonitrile $0.5 \%$ formic acid, elution mode: gradient following the following schedule: $0-45 \mathrm{~min}$ with $8-64 \%$ solvent $\mathrm{B}$, flow $1.0 \mathrm{~mL} \mathrm{~min}{ }^{-1}$ column temperature $40{ }^{\circ} \mathrm{C}$. Spectrum acquisition/detection method: ion polarity positive, scan mode MS, mass range 50 to $1000 \mathrm{~m} / z$, rolling average $2 \times$, spectra rate $2.00 \mathrm{~Hz}$, end plate offset $500 \mathrm{~V}$, capillary voltage $4500 \mathrm{~V}$, gas nebulizer $4.0 \mathrm{Bar}$, dry gas: $9.0 \mathrm{~L} \mathrm{~min}^{-1}$, dry temperature $200{ }^{\circ} \mathrm{C}$.

The samples were prepared with $1 \mathrm{mg}$ of methanolic extract in $1 \mathrm{~mL}$ of HPLC grade methanol. They were subsequently filtered through a $0.45 \mu \mathrm{m}$ pore polytetrafluoroethylene (PTFE) syringe filter. The experimental conditions were developed according to Schmeda-Hirschmann et al. ${ }^{15}$

\section{Animals and experimental design}

This study was registered in the National System for the Management of Genetic Heritage and Associated Traditional Knowledge (SisGen) under No. ACC9622, and approved by the UFMT Ethics Committee on Animal Use (CEUA), under No. 23108.918243/2017-50. Swiss non-isogenic lineage male mice, with an average weight of $35 \mathrm{~g}$ (60 days old), were obtained from the UFMT Central Animal Facility, Cuiabá Campus. The animals were kept under controlled conditions of temperature $\left(22 \pm 2{ }^{\circ} \mathrm{C}\right)$, relative humidity $(55 \pm 10 \%)$, lighting (12-hour light/dark cycle), with a commercial diet (Nuvilab, Colombo, Paraná, Brazil) and filtered water (ad libitum), in polyethylene boxes and a stainless steel grid during the experimental period. The animals were divided into groups $(n=5)$ and treated with water (control group), $0.5 \%$ Tween 20 (Vetec Química, Rio de Janeiro, Brazil) solution (vehicle group) or different extract doses $\left(8,16\right.$ and $32 \mu \mathrm{g} \mathrm{mL}^{-1}$ groups). The doses were defined and adapted according to the study by Oliveira et $a l .{ }^{33}$ The aliquots were prepared in microtubes, diluted in $0.5 \%$ Tween 20 solution and stored at $-4{ }^{\circ} \mathrm{C}$. The animals were treated intragastrically (gavage) with $100 \mu \mathrm{L}$ per animal per day of the dose defined according to the experimental group.

The treatments started after the acclimatization period (15 days) and were carried out for 7 or 30 days. The animals were observed daily for behavior and also for water and feed consumption during the treatment period. Animal weights were obtained at the beginning and at the end of treatment to investigate body weight. The animals were euthanized $24 \mathrm{~h}$ after the last treatment by cervical dislocation and the peritoneal cells were collected by washing the cavity with buffered saline solution (PBS). Next, the spleen was removed to obtain the total spleen cell suspension rich in lymphocytes and macrophages to be used for lymphoproliferation and cytokine analysis. The lung, heart, kidney and liver were also excised to evaluate relative weight, absolute weight and histopathological analysis. Lastly, liver samples were washed with $0.9 \% \mathrm{NaCl}$ (Dinâmica Química Contemporânea, São Paulo, Brazil) and frozen in an ultra-freezer $\left(-80{ }^{\circ} \mathrm{C}\right)$ for oxidative stress analyses.

Histopathological analysis

The heart, liver, lung and kidney were collected and then immediately fixed with $10 \%$ formaldehyde (TRIOL, Sinop, Brazil) in sodium phosphate buffer, $\mathrm{pH} 7.4$, at $4{ }^{\circ} \mathrm{C}$, followed by alcoholic dehydration and diaphanization by xylol (Vetec Química, Rio de Janeiro, Brazil). The tissue fragments were paraffin embedded, cut into $5 \mu \mathrm{m}$ sections (microtome HYRAX M60, Zeiss, Berlin, Germany), dewaxed and stained with haematoxylin-eosin (Vetec Química, Rio de Janeiro, Brazil). The tissues were analyzed using an AxioScope A1 microscope (Carl Zeiss, Berlin, Germany). Histopathological analysis was performed in the form of a score ranging from 0 to 4 , emphasizing data on tissue edema, blood clot, presence of leukocyte infiltrate and damage to the renal tubules, in which 0 means the absence of changes and 4 is the presence of high damage. ${ }^{34}$

\section{Oxidative stress parameters}

The animals' liver samples were thawed and homogenized in buffers according to experimental protocols to analyze the oxidative stress parameters. Next, 
glutathione-S-transferase (GST) enzymatic activity was determined according to Habig et al. ${ }^{35}$ The technique is based on measuring the formation of the GS-DNB adduct, and the result was expressed in $\mu \mathrm{mol}$ GS-DNB $\mathrm{min}^{-1} \mathrm{mg}_{\text {protein }}{ }^{-1}$. Catalase activity (CAT) followed the method of Nelson and $\mathrm{Kiesow}^{36}$ based on the decomposition of $\mathrm{H}_{2} \mathrm{O}_{2}$ and measured through a spectrophotometer at $240 \mathrm{~nm}$ and expressed in $\mu \mathrm{mol} \mathrm{H}_{2} \mathrm{O}_{2} \min ^{-1} \mathrm{mg}$ protein ${ }^{-1}$. The reduced glutathione $(\mathrm{GSH})$ was measured using the colorimetric method by Sedlack and Lindsay ${ }^{37}$ and quantified at $412 \mathrm{~nm}$. The result was expressed in $\mu \mathrm{mol}$ GSH mg protein $^{-1}$ and compared to a standard GSH curve. The method of Buege and $\mathrm{Aust}^{38}$ was followed to determine the levels of substances reactive to thiobarbituric acid (TBARS) to analyze lipid damage in liver tissue. The obtained result was presented as nmol malondialdehyde (MDA) mg protein $^{-1}$ following the MDA calibration curve. Protein content was estimated by spectrophotometry according to Bradford ${ }^{39}$ using bovine serum albumin as a standard. The absorbance of the samples was measured at $595 \mathrm{~nm}$.

Immunomodulatory analysis

\section{Total spleen cell lymphoproliferation assay}

The total spleen cell lymphoproliferation assay was performed using the colorimetric method 3-(4',5'-dimethylthiazol-2-yl)-2,5-diphenyltetrazolium bromide (MTT) following the manufacturer's recommendations (Cell Growth Determination Kit MTT Based, Sigma-Aldrich, St. Louis, Missouri, United States). First, the animals' spleens were removed and transferred to a Petri dish containing Roswell Park Memorial Institute (RPMI) 1640 medium (Cultilab, Campinas, Brazil) and teased on a fine nylon screen. The cell suspension was transferred to a falcon tube and centrifuged at 1,500 rpm for $10 \mathrm{~min}$. Next, $500 \mu \mathrm{L}$ of RPMI 1640 supplemented with $20 \%$ of heat-inactivated fetal bovine serum (FBS) (Cultilab, Campinas, Brazil) was added and the cell concentration was adjusted to $2 \times 10^{4}$ cells $\mathrm{mL}^{-1}$ assessed by Trypan Blue dye exclusion method in a Neubauer chamber. Cells suspensions were distributed in triplicates on 96-well flat-bottomed microculture plates $(50 \mu \mathrm{L}$ per well) and concanavalin A mitogen (ConA, Sigma-Aldrich, St. Louis, Missouri, United States) at $3.5 \mathrm{mg} \mathrm{mL}^{-1}$ was added to each well (50 $\mu \mathrm{L}$ per well). Basal lymphoproliferation activity was determined by adding RPMI $20 \%$ FBS ( $50 \mu \mathrm{L}$ per well) to each well. The plates were cultured for $36 \mathrm{~h}$ at $37^{\circ} \mathrm{C}$ under $5 \% \mathrm{CO}_{2}$ tension. Absorbance values (abs) were measured at $630 \mathrm{~nm}$ in a Thermo Plate Spectrophotometer, microplate reader, TP READER. The lymphoproliferative activity of the spleen cells of treated mice was calculated according to the following formula: lymphoproliferation $(\%)=[($ abs ConA - abs Basal $) /($ abs Basal $)] \times 100$.

\section{Cytokine determination in the culture supernatant}

Quantification of cytokine in culture supernatant of total spleen cell suspension was measured by enzyme-linked immunosorbent assay (ELISA) using commercial kits (eBioscience, San Diego, United States), and following the manufacturer's protocol. Cell suspensions were adjusted to $4 \times 10^{6}$ cells $\mathrm{mL}^{-1}$ in RPMI $164020 \%$ FBS by Trypan Blue dye exclusion method in a Neubauer chamber, and were distributed ( $50 \mu \mathrm{L}$ per well) in triplicates in 96-well flat-bottomed microculture plates. The cell culture supernatant stimulated in vitro with the ConA mitogen $\left(3.5 \mu \mathrm{g} \mathrm{mL}^{-1}, 50 \mu \mathrm{L}\right.$ per well) for $24 \mathrm{~h}$ was used to measure interleukin-4 (IL-4, catalog No. 88-7044-76) and interleukin-10 (IL-10, catalog No. 88-7104-76). IL12p70 (Catalog No. 88-7121-76) and tumor necrosis factor (TNF- $\alpha$, catalog No. 88-7324-76) were measured in the cell culture supernatant stimulated in vitro with formolized Staphylococcus aureus Cowan strain 1 cells in aqueous suspension (1:5,000, $50 \mu \mathrm{L}$ per well, SAC, SigmaAldrich, St. Louis, Missouri, United States) for $48 \mathrm{~h}$. The supernatants of the culture were collected and frozen at $-80^{\circ} \mathrm{C}$ for further cytokine quantification.

Sample absorbance reading was performed in a Thermo Plate Spectrophotometer, microplate reader, TP READER at $450 \mathrm{~nm}$. Data from the standard curve were submitted to linear regression analysis and the results were expressed as $\mathrm{pg} \mathrm{mL}^{-1}$.

\section{Peritoneal macrophage suspension}

Peritoneal macrophages were obtained by washing the cavity with cold PBS $(10 \mathrm{~mL})$, followed by abdominal massage for $30 \mathrm{~s}$ and transferring the collected peritoneal fluid to falcon tubes. This procedure was performed twice and the falcon tubes were kept in an ice bath. Peritoneal fluids were centrifuged under refrigeration at 1,500 rpm for $10 \mathrm{~min}$. Next, $1 \mathrm{~mL}$ of RPMI 1640 supplemented with $10 \%$ FBS was added and the cell concentration was adjusted to $2 \times 10^{6}$ cells $\mathrm{mL}^{-1}$ (Trypan Blue dye exclusion method in a Neubauer chamber). Cell suspensions were distributed in triplicates in 96-well flat-bottomed microculture plates $(100 \mu \mathrm{L}$ per well $)$ and cultured for $2 \mathrm{~h}$ at $37{ }^{\circ} \mathrm{C}$ under $5 \% \mathrm{CO}_{2}$. Wells were rinsed with $100 \mu \mathrm{L}$ of RPMI to remove non-adherent cells. Next, $200 \mu \mathrm{L}$ of RPMI 10\% FBS was added to each well and the adherent cells (macrophages) were cultured for $36 \mathrm{~h}$ at $37{ }^{\circ} \mathrm{C}$ under $5 \% \mathrm{CO}_{2}$ tension. 
Assay for spontaneous release of $\mathrm{H}_{2} \mathrm{O}_{2}$

Spontaneous production of $\mathrm{H}_{2} \mathrm{O}_{2}$ by peritoneal macrophages of treated mice was determined according to Pick and Mizel. ${ }^{40}$

After $36 \mathrm{~h}$, the macrophage culture supernatant was collected and reserved for the NO dosage. Next, $100 \mu \mathrm{L}$ of phenol red solution containing $140 \mathrm{mM}$ sodium chloride $(\mathrm{NaCl}), 10 \mathrm{mM}$ dibasic potassium phosphate $\left(\mathrm{K}_{2} \mathrm{HPO}_{4}\right.$, Vetec Química, Rio de Janeiro, Brazil), $5.5 \mathrm{mM}$ dextrose (Vetec Química, Rio de Janeiro, Brazil) and $5.5 \mathrm{mM}$ peroxidase (Sigma-Aldrich, St. Louis, Missouri, United States) were added to the macrophage monolayer adhered to wells in order to determine the $\mathrm{H}_{2} \mathrm{O}_{2}$. The microplate was incubated at room temperature and protected from light for $60 \mathrm{~min}$. The reaction was stopped with $10 \mu \mathrm{L}$ of $1 \mathrm{M}$ sodium hydroxide $(\mathrm{NaOH}$, Vetec Química, Rio de Janeiro, Brazil) and the absorbance measured at $630 \mathrm{~nm}$ in a Thermo Plate spectrophotometer, microplate reader, TP READER. The blank was constituted by the phenol red and $1 \mathrm{M} \mathrm{NaOH}$ solution. The $\mathrm{H}_{2} \mathrm{O}_{2}$ concentration produced by macrophages was determined from a standard curve of known $\mathrm{H}_{2} \mathrm{O}_{2}$ solution concentrations and considering the average value of the samples in triplicate. The results were expressed as $\mathrm{nM} 2 \times 10^{5}$ cell $^{-1}$.

\section{Assay for spontaneous release of NO*}

$\mathrm{NO}^{*}$ production was measured in the previously reserved macrophage culture supernatant by the colorimetric method based on the Griess reaction. ${ }^{41}$ Griess reagent $(100 \mu \mathrm{L})$ was added to the supernatants. Griess reagent consists of $1 \% N$-(1-naphthyl)-ethylenediamine dihydrochloride (NEED, Sigma-Aldrich, St. Louis, Missouri, United States) diluted in distilled water, and 1\% sulfanilamide (SigmaAldrich, St. Louis, Missouri, United States) diluted in 5\% phosphoric acid $\left(\mathrm{H}_{3} \mathrm{PO}_{4}\right.$, Vetec Química, Rio de Janeiro, Brazil), being mixed in equal volumes at the reaction time. Absorbance values were measured at $492 \mathrm{~nm}$ on a Thermo Plate spectrophotometer, microplate reader, TP READER. The blank was constituted by the Griess reagent. The NO concentration produced by macrophages was determined from a standard curve of known concentrations of sodium nitrite solution $\left(\mathrm{NaNO}_{2}\right.$, Vetec Química, Rio de Janeiro, Brazil), and considering the average value of the samples in triplicate. The results were expressed as $\mathrm{nM} 2 \times 10^{5}$ cell $^{-1}$.

\section{Statistical analysis}

The obtained results were submitted to the KolmogorovSmirnov normality test. When presenting normal distribution, the values were analyzed by one-way analysis of variance (ANOVA; mean \pm standard deviation), followed by the Tukey's test. When they were not normally distributed the data were analyzed by non-parametric ANOVA (Kruskal-Wallis; median \pm interquartile range), followed by Dunn's test to determine significant differences across groups. Statistical significance was set at $p<0.05$.

\section{Results and Discussion}

UHPLC-DAD and electrospray ionization tandem mass spectrometry (ESI-MS-MS) results

The chemical structures of the compounds found in the methanolic extract of $R$. marina poison are shown in Scheme 1. Next, a chromatogram generated by the UHPLC-DAD-ESI-MS-MS system (Figure 2) shows the presence of 15 peaks in the extract separated in order of polarity. The information on retention time $\left(t_{R}\right)$, relative peak area $(\%),[\mathrm{M}+\mathrm{H}]^{+}$, fragments and compound identification are summarized in Table 1.
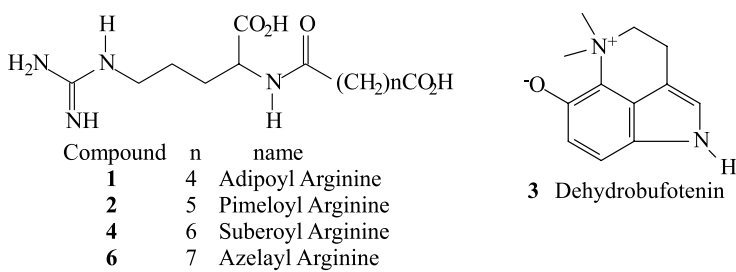

Azelayl Arginine

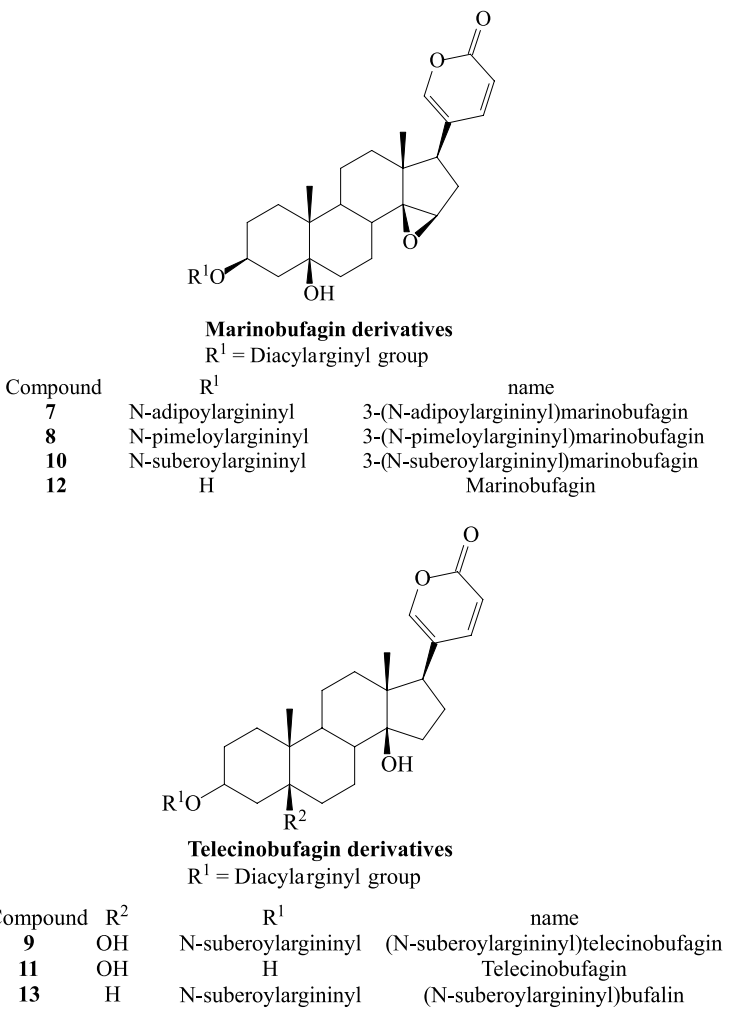

Scheme 1. Chemical structure of the compounds present in the methanolic extract obtained from the paratoid gland secretion from $R$. marina. 
According to the data obtained by MS/MS, we proposed a fragmentation pattern for diacyl arginine compounds derived based on compound $\mathbf{1}$ and extended it to other compounds. Our proposal is that compound $\mathbf{1}$ initially suffered the loss of the diacyl group generating an ionic fragment with $m / z 175[\mathrm{M}-130+2 \mathrm{H}]$; the second fragmentation was the loss of the $\mathrm{NH}_{2}$ group, generating an ionic fragment $\mathrm{m} / \mathrm{z} 158[\mathrm{M}-144+\mathrm{H}]$; and finally the loss of the amine group, generating an ionic fragment $m / z 116[\mathrm{M}-188+\mathrm{H}]$, as proposed in

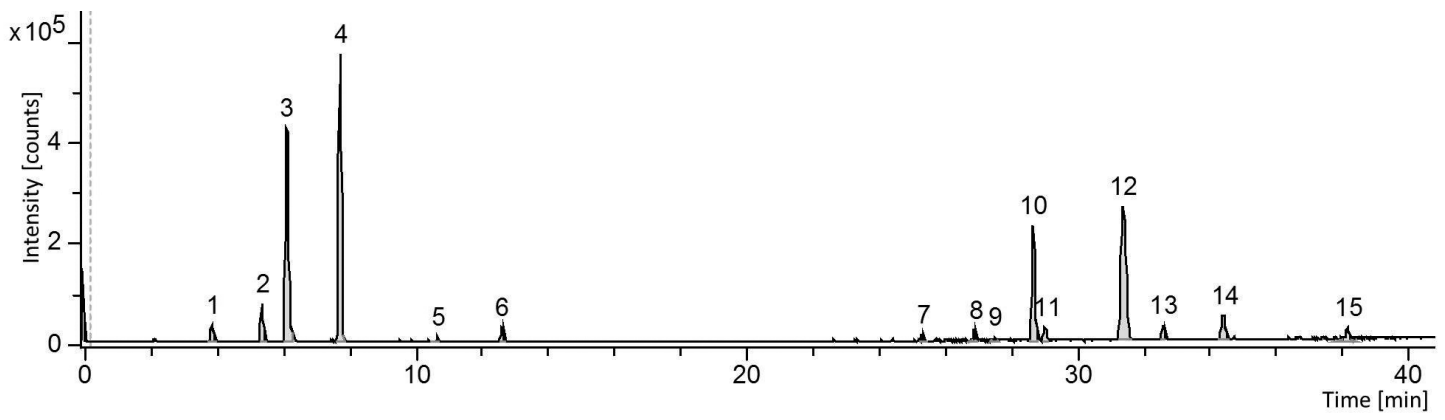

Figure 2. Chromatogram of the methanolic extract from $R$. marina poison.

Table 1. Experimental and theoretical physical data of the methanolic extract from R. marina poison by UHPLC-DAD-ESI-MS-MS and identification of compounds

\begin{tabular}{|c|c|c|c|c|c|c|}
\hline Compound & $\mathrm{t}_{\mathrm{R}} / \min$ & $\begin{array}{c}\text { Relative peak } \\
\text { area / \% }\end{array}$ & $\begin{array}{c}{[\mathrm{M}+\mathrm{H}]^{+} \text {experimental / }} \\
\text { calculated }\end{array}$ & $\begin{array}{l}\text { MS/MS (relative } \\
\text { intensity) }\end{array}$ & $\begin{array}{l}\text { Molecular } \\
\text { formula }\end{array}$ & Identification \\
\hline 1 & 3.4 & 1.7 & $303.1601 / 302.159020$ & $\begin{array}{l}175.1199(65), \\
158.0918(99), \\
116.0706(100)\end{array}$ & $\mathrm{C}_{12} \mathrm{H}_{22} \mathrm{~N}_{4} \mathrm{O}_{5}$ & adipoyl arginine \\
\hline 2 & 5.5 & 3.2 & $317.1745 / 316.174670$ & $\begin{array}{c}175.1166(91) \\
158.0915(100) \\
116.0716(94)\end{array}$ & $\mathrm{C}_{13} \mathrm{H}_{24} \mathrm{~N}_{4} \mathrm{O}_{5}$ & pimeloyl arginine \\
\hline 3 & 6.2 & 24.5 & $203.1126 / 204.126263$ & 188.0893 & $\mathrm{C}_{12} \mathrm{H}_{16} \mathrm{~N}_{2} \mathrm{O}$ & dehydrobufotenin \\
\hline 4 & 7.8 & 26.0 & $331.1898 / 330.190320$ & $\begin{array}{c}175.1158(100) \\
158.0911(91) \\
116.0707(68)\end{array}$ & $\mathrm{C}_{14} \mathrm{H}_{26} \mathrm{~N}_{4} \mathrm{O}_{5}$ & suberoyl arginine \\
\hline 5 & 10.8 & 0.3 & 345.2040 & $\begin{array}{c}264.1648(47) \\
175.1183(100) \\
158.0907(44)\end{array}$ & & not identified \\
\hline 6 & 12.7 & 1.2 & $345.2049 / 344.205970$ & $\begin{array}{l}175.1152(95) \\
158.0925(100)\end{array}$ & $\mathrm{C}_{15} \mathrm{H}_{28} \mathrm{~N}_{4} \mathrm{O}_{5}$ & azelayl arginine \\
\hline 7 & 25.4 & 0.5 & $685.3671 / 684.373430$ & $303.1651(83)$ & $\mathrm{C}_{36} \mathrm{H}_{52} \mathrm{~N}_{4} \mathrm{O}_{9}$ & 3-(N-adipoylargininyl)marinobufagin \\
\hline 8 & 27.0 & 1.0 & 699.3837 / 698.389080 & $317.1798(68)$ & $\mathrm{C}_{37} \mathrm{H}_{54} \mathrm{~N}_{4} \mathrm{O}_{9}$ & 3-(N-pimeloylargininyl)marinobufagin \\
\hline 9 & 27.6 & 0.2 & $715.4154 / 714.420380$ & $331.1967(63)$ & $\mathrm{C}_{38} \mathrm{H}_{58} \mathrm{~N}_{4} \mathrm{O}_{9}$ & 3-(N-suberoylargininyl)telecinobufagin \\
\hline 10 & 28.7 & 11.0 & $713.4001 / 712.404730$ & $331.1962(100)$ & $\mathrm{C}_{38} \mathrm{H}_{56} \mathrm{~N}_{4} \mathrm{O}_{9}$ & 3-(N-suberoylargininyl)marinobufagin \\
\hline 11 & 29.1 & 1.4 & 403.2377 / 402.240624 & $\begin{array}{l}385.2300(24) \\
349.2099(96)\end{array}$ & $\mathrm{C}_{24} \mathrm{H}_{34} \mathrm{O}_{5}$ & telecinobufagin \\
\hline 12 & 31.4 & 21.5 & 401.2237 / 400.224974 & $383.2156(100)$ & $\mathrm{C}_{24} \mathrm{H}_{32} \mathrm{O}_{5}$ & marinobufagin \\
\hline 13 & 32.6 & 1.4 & 699.4198 / 698.425465 & $\begin{array}{l}681.4073(10), \\
331.1961(100)\end{array}$ & $\mathrm{C}_{38} \mathrm{H}_{58} \mathrm{~N}_{4} \mathrm{O}_{9}$ & 3-(N-suberoylargininyl)bufalin \\
\hline 14 & 34.5 & 3.5 & $450.2542 /-$ & $\begin{array}{c}409.2283(40) \\
387.2461(100) \\
309.1495(9)\end{array}$ & & not identified \\
\hline 15 & 38.2 & 2.5 & $423.1900 /-$ & $\begin{array}{c}407.2132(45) \\
385.2328(100) \\
261.1276(26)\end{array}$ & & not identified \\
\hline
\end{tabular}

$\mathrm{t}_{\mathrm{R}}$ : retention time. 
Scheme 2. This proposal was based on the results obtained experimentally and compared with the work done by Gao et $a l .{ }^{42}$ and Schmeda-Hirschmann et al.$^{43}$ for the adipoyl arginine compound in the positive ionization mode. It was observed that the compounds 1, 2, 4 and $\mathbf{6}$ showed the same fragmentation pattern as described in Scheme 2. These compounds were identified as arginine diacids and were named adipoyl arginine, pimeloyl arginine, suberoyl arginine and azelaylarginine, respectively, and had their identification based on the recent studies by Sinhorin and co-workers. ${ }^{32}$

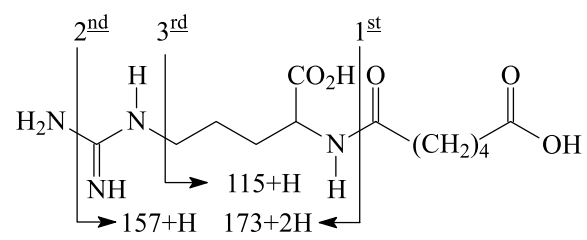

Scheme 2. Proposed fragmentation of adipoyl arginine according to the fragmentation presented in the analyzes.

Compound $\mathbf{3}$ was identified as dehydrobufotenin. Compounds 7, 8 and $\mathbf{1 0}$ are derived from the steroid marinobufagin, and have been identified as 3-( $N$-adipoylargininyl)marinobufagin, 3-( $N$-pimeloylargininyl)marinobufagin, and 3-( $N$-suberoylargininyl) marinobufagin, respectively. Compound 9 is derived from the steroid telecinobufagin and identified as 3-(N-suberoylargininyl)telecinobufagin. Compound $\mathbf{1 3}$ is derived from the steroid bufalin, and has been described as 3-( $N$-suberoylargininyl)bufalin. ${ }^{15,43-45}$ Compounds derived from cardiotonic steroids showed a fragmentation pattern related to arginine loss which only differed in the diacid. ${ }^{15}$

Compounds $\mathbf{1 1}$ and $\mathbf{1 2}$ are free steroids identified as telecinobufagin and marinobufagin. ${ }^{43,45}$ Only compounds $\mathbf{5}$, $\mathbf{1 4}$ and $\mathbf{1 5}$ were not found in the literature.

According to Table 1, it can be seen that the major compounds present in the methanol extract of $R$. marina are compounds 3 (24.5\%), $\mathbf{4}$ (26.0\%), 10 (11.0\%) and 12 $(21.5 \%)$, together corresponding to $83.0 \%$ of the sample. These compounds represent four distinct classes of compounds, with 3 being an indolic alkaloid, 4 belongs to the class of derived argininyls, compound $\mathbf{1 0}$ is a steroid linked to an argininyl, and $\mathbf{1 2}$ belongs to the class of cardiotonic steroids in their free form. These compounds are extremely important for the survival of these animals in both physiological functions and against predators and microorganisms. ${ }^{14}$ Studies have shown that the same species of toads obtained from different geographical regions and under different climate conditions and other environmental factors show differences in their chemical compositions. ${ }^{46}$ Thus, analysis of the chemical profile is crucial for developing new drugs. Studies ${ }^{14}$ have demonstrated the biological activity of aqueous molecules and extracts obtained from the secretion expelled by the toads' glands, showing bufadienolides in their composition. Dry secretion from the glands and skin of the Chinese toad (Bufo bufo argarizans) has been used in traditional Chinese medicine for several centuries to treat infections and inflammations, including cancer. ${ }^{46-48}$

The chemical constituents in the Bufonidae family have therapeutic potential for treating allergies, inflammation, cancer, infections and other diseases. ${ }^{49}$ Different bufadienolides have shown different inhibitory activity in $\mathrm{Na}^{+} / \mathrm{K}^{+}$-ATPase. ${ }^{50}$ Machado et al. ${ }^{51}$ performed tests with marinobufagin alone and found antiproliferative activity in human leukemia cells. Cunha-Filho et al. ${ }^{13}$ verified the antimicrobial effect of telecinobufagin and marinobufagin from the poison secretion of Buforubescens (Rhinella rubescens). In addition, bufadienolides isolated from Rhinella jimi showed antiparasitic activity against Trypanosoma cruzi trypomastigotes and Leishmania chagasi promastigotes. ${ }^{52}$ Schmeda-Hirschmann ${ }^{15}$ found that the most active antiproliferative compounds in Rhinella schneideri poison are bufadienolides, with marinobufagin being the most active, but the presence of alkaloids as minor constituents in the same fractions may play an important role in the effect. Amphibian poison has been shown to be a rich source of bioactive compounds which needs to be studied, as they represent great potential for developing new drugs. ${ }^{14}$

However, it is important to note that the poison can be lethal to other animals and is also a potential danger to children and pets, especially in contact with oral mucosa or the eyes. ${ }^{44,53}$ Most intoxicated patients have gastrointestinal symptoms consisting of nausea, vomiting, and abdominal discomfort. ${ }^{54}$ In addition, toad toxin poisoning is manifested by digitalis toxicity-like cardiac effects, including bradycardia, atrioventricular conduction block, ventricular tachycardia, ventricular fibrillation, and sudden death. ${ }^{54}$

In this sense, we evaluated the body weight, food consumption and organ weight of the treated mice as a toxicity parameter of methanolic extract from $R$. marina. Histopathological analysis of the heart, liver, lung and kidneys was also performed.

Analysis of body weight, food consumption and organ weight

Body weight, food consumption and organ weight were analyzed for possible poison toxicity. Such assessments are important because toxic products usually induce changes in the animal's behavior with reduced body weight and appetite. ${ }^{55}$ As in the work by Oliveira et al. ${ }^{33}$ water and feed consumption, as well as body weight gain did not show any 
significant difference between the evaluated groups (data not shown). We can only mention the relative weight of the lung which differed between the 8 and $32 \mu \mathrm{g} \mathrm{mL}^{-1}$ doses at 7 days of treatment (data not shown). However, the analysis of the absolute and relative weight of the organs showed no difference in relation to the control group and vehicle group (data not shown).

\section{Histopathological analysis}

Histopathological analysis of the heart, liver, kidney and lung showed that treatment with $R$. marina poison extract was able to induce tissue edema, intravascular clot, caused damage to the renal tubule architecture and induced leukocyte infiltrate in relation to the control and vehicle group. Figure 3 shows the histopathological analysis of the lung as a representative example of tissue damage considered in the study.

The heart and kidney showed intermediate histological damage, presenting edema, intravascular clots and leukocyte infiltrate with scores 1 and 2, mainly at the dose $32 \mu \mathrm{g} \mathrm{mL}^{-1}$ at 7 and 30 days of treatment. The liver showed less changes, with edema showing a score of 1 at 7 and 30 days. The effects on the lung were more pronounced with edema, clots and peribronchiolar leukocyte infiltrates (score 1 and 2) at 7 and 30 days of treatment, mainly at the dose $32 \mu \mathrm{g} \mathrm{mL} \mathrm{m}^{-1}$. Tissue damage was dose dependent. The same was observed about time, since the 30-day treatment showed more edema, clots and leukocyte infiltrates than the acute treatment.

In this study, the lung seems to be the most sensitive organ to the action of the compounds present in the extracts used, with a reduction in relative weight and a more intense presence of edema, clots and peribronchiolar leukocyte infiltrates. An important factor to consider may be the maximum treatment time (30 days), being possible that these changes could be seen macroscopically with a longer treatment time, showing the toxicity observed microscopically. Taken together, the histological changes observed were restricted to lighter scores (1 and 2) and did not affect the animals' habits.

This work presents a preliminary histopathological analysis of $R$. marina poison extract, being the first in the literature, and our results seem to be in agreement with Banfi et al. ${ }^{56}$ These authors demonstrated that dehydrobufotenin, marinobufagin and bufalin extracted from $R$. marina have sufficiently acceptable toxicity properties by Lipinsk's rule and Gleeson's theory using a docking assay. ${ }^{56}$ Dehydrobufotenin compound $\mathbf{3}$, marinobufagin compound $\mathbf{1 2}$ and bufalin compound $\mathbf{1 3}$ are present in the methanol extract of $R$. marina and together correspond to $47.4 \%$ of the sample.

However, Banfi et al. ${ }^{56}$ also demonstrated that marinobufotoxin has unfavorable pharmacokinetic properties and may be toxic. Therefore, the lighter scores of histological changes observed in our study can be the result of the other compounds present in the methanolic extract.

Considering that the histological changes observed were restricted to lighter scores and the extract treatment did not affect the animals' habits, we evaluated the effects of $R$. marina methanolic extract on the oxidative stress parameters and its immunomodulatory action.

\section{Oxidative stress parameters}

The liver is one of the most important organs of the human body and plays an essential role in the metabolism, immune response, and detoxification of the body. ${ }^{57}$ In this

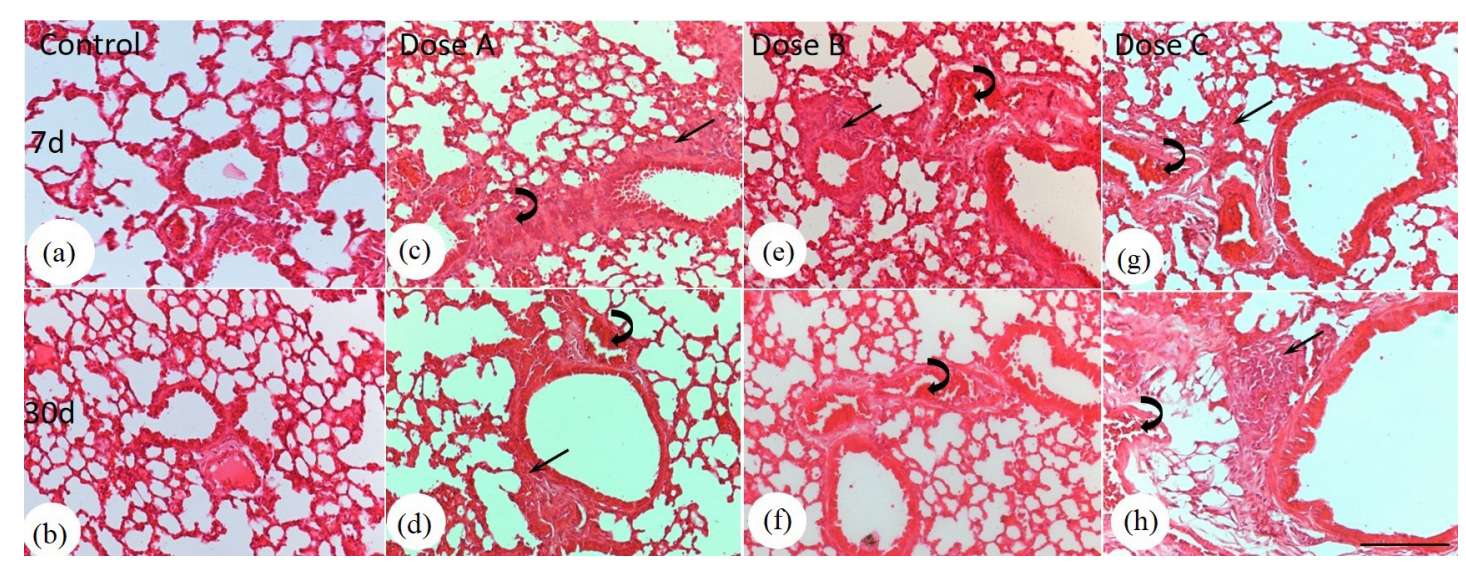

Figure 3. Histopathological analysis of lung after treatment with methanolic extract of Rhinella marina poison. Mice treated with water (a, control group) and $0.5 \%$ Tween 20 solution (b, vehicle group) showed no damage to the pulmonary architecture. Mice treated with $8 \mu \mathrm{g} \mathrm{mL} \mathrm{m}^{-1}$ (c), $16 \mu \mathrm{g} \mathrm{mL} \mathrm{m}^{-1}$ (e) and $32 \mu \mathrm{g} \mathrm{mL} \mathrm{L}^{-1}$ dose ( $\mathrm{g}$ ) of $R$. marina extract for 7 days presented tissue edema (curved arrow), intravascular blood clot and a small peribronchiolar leukocyte infiltrate (arrow). (d, f, h) Mice treated with increasing doses of $R$. marina extract for 30 days showed the same histological damages. Hematoxylin-eosin stains. Barr $=100 \mu \mathrm{m}, \mathrm{n}=5$. 
context, we decided to investigate some oxidative stress parameters after exposing the mice at different times to the methanolic extract of $R$. marina poison, as the animals received the extracts via gavage, and the liver is essential for their metabolization. Mitochondria play an important role among the various factors which can trigger oxidative stress, constituting the site within the cell where the largest amount of reactive oxygen species (ROS) are generated..$^{58}$ Thus, CAT is an important enzymatic antioxidant which captures $\mathrm{H}_{2} \mathrm{O}_{2}$ molecules and converts them to oxygen and water molecules. ${ }^{59}$ In the same way, it is also a very important enzyme in the metabolism of xenobiotics, having its active function in the liver, ${ }^{60}$ such as GST. ${ }^{61}$ In addition, GSH maintains the stability of the thiol groups of proteins, reduces disulfide bonds induced by oxidative stress, neutralizes free radicals, and behaves as an indicator of the cell's ability to maintain its homeostasis; therefore, it is considered a very important agent of the cell antioxidant defense system. ${ }^{62}$ Lipid peroxidation using the TBARS method demonstrates malondialdehyde (MDA) formation, ${ }^{63}$ causes oxidative stress and leads to signaling loss of cellular function. ${ }^{64}$

In our study, we noticed that the extract from the $R$. marina poison had a biphasic effect between doses in the 7-day treatment, promoting an increase in CAT enzyme activity in animals treated with the $8 \mu \mathrm{g} \mathrm{mL}^{-1}$ concentration compared to animals treated with the $16 \mu \mathrm{g} \mathrm{mL} \mathrm{m}^{-1}$ dose. However, the CAT antioxidant activity did not change in
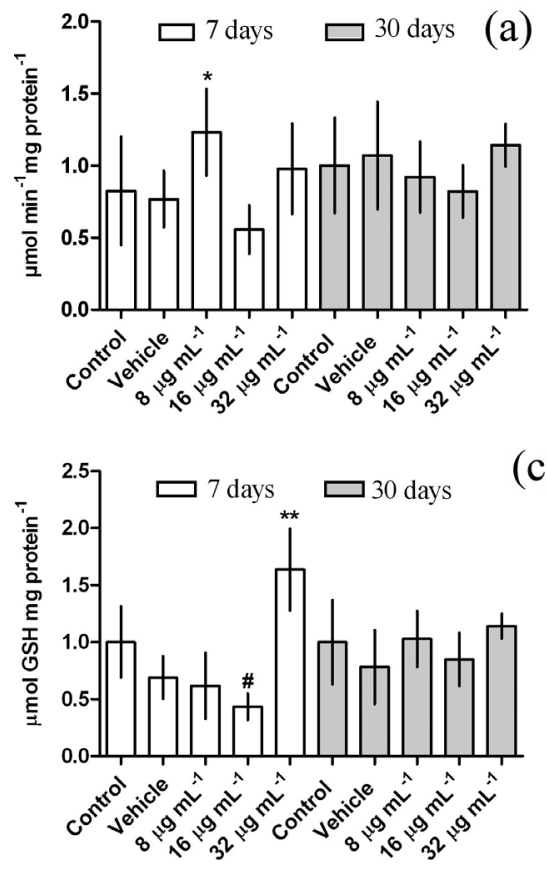

(c)

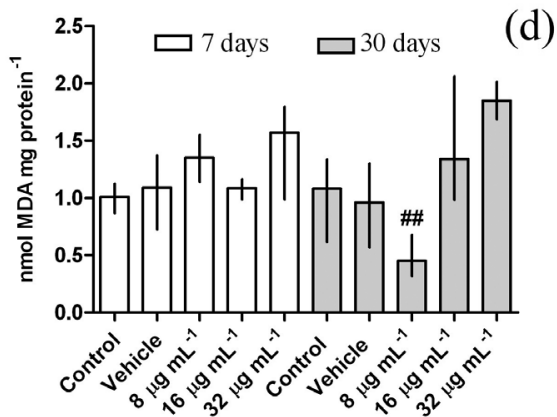

Figure 4. Effect of different doses of the R. marina poison methanol extract on oxidative stress parameters in the liver of mice. Graphs of (a) CAT, (b) GST, (c) GSH and (d) TBARS ( $\mathrm{n}=5-6)$. One-way ANOVA followed by the Tukey's test, ${ }^{*} p<0.01$ compared to $16 \mu \mathrm{g} \mathrm{mL}^{-1}$ dose; $* * p<0.0001$ compared to all treatments (seven days); ${ }^{\#} p<0.05$ compared to control (seven days). ${ }^{\# \#} p<0.01$ compared to $32 \mu \mathrm{g} \mathrm{mL}^{-1}$ dose (thirty days). For TBARS, a non-parametric one-way analysis (Kruskal-Wallis), followed by Dunn's test. 
that analyzes of other important enzyme activities such as superoxide dismutase and glutathione peroxidase will complement and provide more answers about the antioxidant activity of this extract. Corroborating the histopathological findings of the liver, which showed few alterations, leads us to suggest that some substances present in the extract may have contributed to the minor damage observed in this tissue; furthermore, no lipoperoxidation was observed in relation to the doses administered when compared to the control mice.

It is important to highlight the increase in GSH levels at $32 \mu \mathrm{g} \mathrm{mL}^{-1}$ dose after 7 days of treatment in comparison with the other groups. Intracellular GSH is important for macrophage activation; an increase in the GSH level stimulates IL-12 production and antigen processing. ${ }^{65}$ Thus, compounds which are able to increase GSH levels have been proposed as new tools for the treatment against different pathogens by acting as both immunomodulators and antimicrobials. ${ }^{66}$ In this regard, we evaluated the immunomodulatory effects of methanolic extracts in mice.

\section{Immunomodulatory analysis}

The immunomodulatory activity of the extract was evaluated based on the lymphoproliferative response and the capacity for in vitro cytokines production by total spleen cells of mice treated with the $R$. marina poison for 7 and 30 days. In addition, we also evaluated in vitro spontaneous release of $\mathrm{NO}^{*}$ and $\mathrm{H}_{2} \mathrm{O}_{2}$ by peritoneal macrophage.

The lymphoproliferative activity showed no difference between the groups treated for 7 or 30 days (data not shown).

No significant difference was found regarding the in vitro cytokine production determination in the IL-4 production in the treatment of 7 days or 30 days (data not shown). The same was observed in IL-10 at 7 and 30 days of treatment (data not shown). IL-4 and IL-10 are pleiotropic anti-inflammatory cytokines which mainly work by suppressing pro-inflammatory actions. ${ }^{67}$ IL-4 is a multifunctional cytokine which regulates innate and adaptive immunity produced by CD4 and CD8 T cells, NKT cells, eosinophils, mast cells and basophils. ${ }^{68} \mathrm{It}$ is important in differentiating Th2 cells and limiting Th1 responses by acting on activated macrophages, reducing the effects of IL- 1 , TNF- $\alpha$, IL- 6 and IL- 8 cytokines, and inhibiting the production of free radicals. ${ }^{69}$

IL-10 is a non-glycosylated polypeptide expressed by many types of cells in the immune system and neuroendocrine and neural tissues. ${ }^{69,70}$ It inhibits proinflammatory cytokines, mainly TNF- $\alpha$, IL-1 and IL-6 produced by activated macrophages and monocytes, stimulating the endogenous production of anti-inflammatory cytokines. $^{69}$

Unlike anti-inflammatory cytokines, we observed a significant difference in the production of pro-inflammatory cytokines. The IL-12p70 production capacity in response to SAC stimulus was reduced in the group treated with the $32 \mu \mathrm{g} \mathrm{mL}^{-1}$ dose at 7 days of treatment when compared to the control group (also stimulated). In addition, basal IL-12p70 production increased in the $8 \mu \mathrm{g} \mathrm{mL}^{-1}$ group compared to control and the $32 \mu \mathrm{g} \mathrm{mL} \mathrm{m}^{-1}$ groups at 7 days (Figure 5a). The IL-12p70 production in the groups treated for 30 days showed no difference (Figure $5 \mathrm{~b}$ ). This cytokine acts on the specific receptor expressed in NK cells and activated T lymphocytes. ${ }^{70}$ An important action of IL-12p70 is IFN- $\gamma$ production, which is a cytokine involved in immune response to infections by intracellular microorganisms, as it is a potent activator for the macrophage, $\mathrm{T}$ lymphocyte and neutrophil functions..$^{71,72}$

TNF- $\alpha$ production was also evaluated and showed no significant difference in the 7-day treatment (Figure 5c). In contrast, the TNF- $\alpha$ basal production capacity was significant at 30 days of treatment. The $32 \mu \mathrm{g} \mathrm{mL}^{-1}$ dose was higher than the 8 and $16 \mu \mathrm{g} \mathrm{mL}^{-1}$ doses as well as the control and vehicle groups (Figure 5d). TNF- $\alpha$ is produced by Th1 cells and macrophages, being the main mediator of the inflammatory process. ${ }^{73}$

Macrophages act as antigen-presenting cells for the immune system, processing and presenting antigens to initiate $\mathrm{T}$ cell-mediated immunity, and produce proinflammatory cytokines such as IL-1, IL-6, IL-12, TNF- $\alpha$ and chemokines. In addition, macrophages contribute to the inflammatory response by producing ROS and reactive nitrogen species (RNS) ${ }^{26}$ In this context, determining the $\mathrm{H}_{2} \mathrm{O}_{2}$ and $\mathrm{NO}^{*}$ spontaneous release after mice treatment contributes to identify the effects of the methanolic extract from $R$. marina poison on macrophage activity.

NO^ production did not show any significant difference between the treated groups in all experimental periods 7 and 30 days (Figure 6a). The spontaneous release of $\mathrm{H}_{2} \mathrm{O}_{2}$ by the peritoneal macrophages showed no statistically significant difference between the groups treated at 7 days. Furthermore, an increase in the $\mathrm{H}_{2} \mathrm{O}_{2}$ production was observed in the $16 \mu \mathrm{g} \mathrm{mL}^{-1}$ dose in the 30-day treatment when compared to the $8 \mu \mathrm{g} \mathrm{mL}^{-1}$ dose (Figure $6 \mathrm{~b}$ ), however there was no difference in relation to the control and vehicle groups.

According to the results, the immunomodulatory activity of the poison extract appears to be concentrated in modulating the activity of immune cells in terms of IL-12p70 production at 7 days of treatment and TNF- $\alpha$ at 30 days of treatment. 

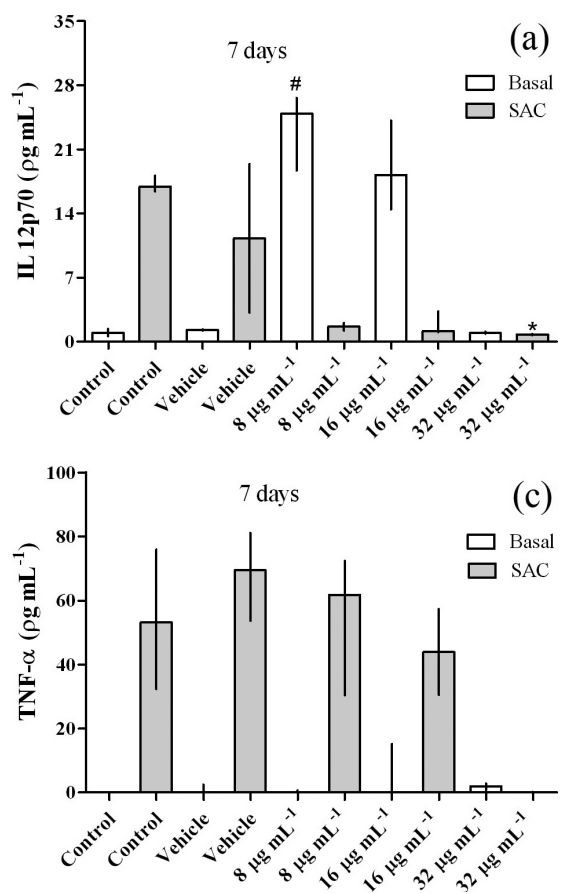

(a)

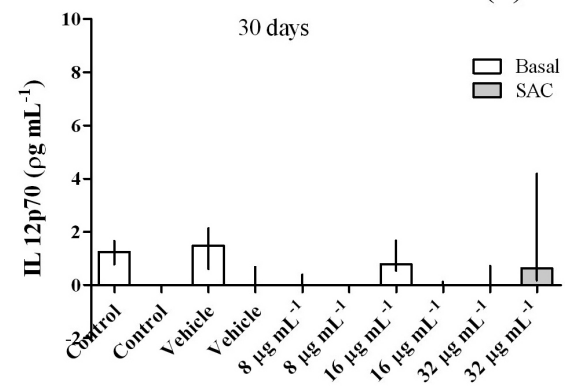

(d)

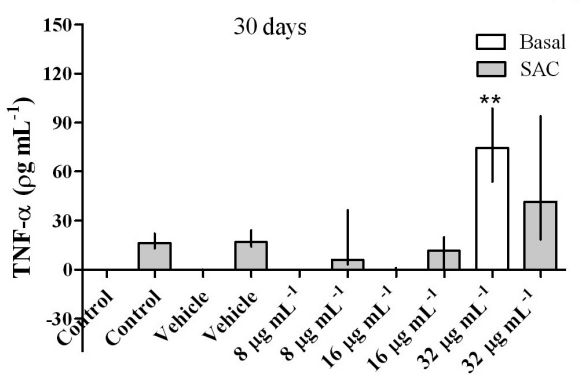

Figure 5. IL12p70 and TNF- $\alpha$ determination in the total spleen cell culture supernatant from mice treated with different doses of the $R$. marina poison methanol extract $\left(8,16\right.$ and $\left.32 \mu \mathrm{g} \mathrm{mL} \mathrm{mL}^{-1}\right)$ during 7 and 30 days $(\mathrm{n}=5-6)$. The control group was treated with water and the vehicle group was treated with $0.5 \%$ Tween 20 solution. Quantification of cytokines was done by ELISA and the cell culture was in vitro stimulated with formolized Staphylococcus aureus Cowan strain 1 cells in aqueous suspension (1:5,000, SAC) for $48 \mathrm{~h}$. Basal cytokine production capacity was also evaluated. (a) IL12p70 at 7 days. (b) IL12p70 at 30 days. (c) TNF- $\alpha$ at 7 days. (d) TNF- $\alpha$ at 30 days. Non-parametric one-way analysis ANOVA (Kruskal-Wallis), followed by Dunn's test. ${ }^{*} p<0.0001$ compared to basal control group; * $p<0.0001$ compared to SAC control group; ** $p<0.0001$ compared to basal control group, vehicle, $8 \mu \mathrm{g} \mathrm{mL}-1$ dose and $16 \mu \mathrm{g} \mathrm{mL}{ }^{-1}$ dose.
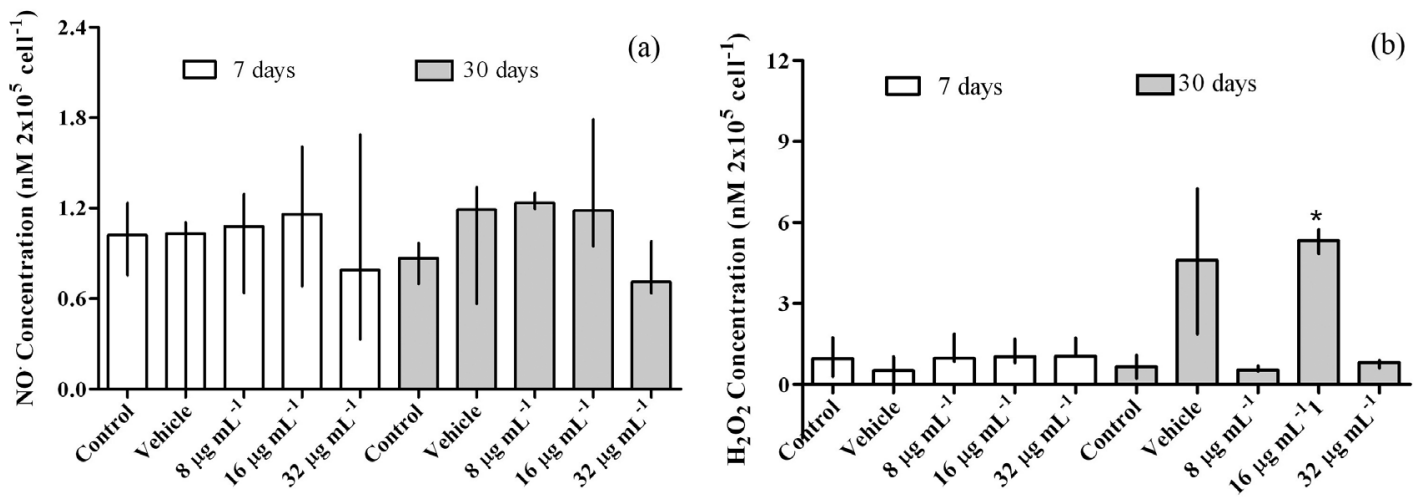

Figure 6. Spontaneous release of $\mathrm{NO}^{*}$ and $\mathrm{H}_{2} \mathrm{O}_{2}$ by peritoneal macrophages from mice treated with different doses of the $R$. marina poison methanol extract $\left(8,16\right.$ and $\left.32 \mu \mathrm{g} \mathrm{mL}^{-1}\right)$ during 7 and 30 days $(\mathrm{n}=5-6)$. The control group was treated with water and the vehicle group was treated with $0.5 \%$ Tween 20 solution. (a) $\mathrm{NO}^{*}$; (b) $\mathrm{H}_{2} \mathrm{O}_{2}$; non-parametric one-way analysis ANOVA (Kruskal-Wallis), followed by Dunn's test. * $p<0.01$ compared to $8 \mu \mathrm{g}$ mL ${ }^{-1}$ dose (30 days).

IL-12p70 and TNF- $\alpha$ are important cytokines for developing immune responses which are produced by macrophages during innate responses, capable of guiding the formation of more efficient specific immune responses. ${ }^{74}$ IL-12p70 is an important cytokine for developing cellular immune responses, favoring $\mathrm{NK}$ and Th1 cell activity and producing IFN- $\gamma,{ }^{75}$ while TNF- $\alpha$ favors developing the inflammatory process which is important for recruiting defense cells to the infection site. ${ }^{73}$ It is important to note that the treatment modulated the production of these cytokines in animals, and this effect may be related to tissue damage observed microscopically as a consequence of a low intensity inflammatory process (scores 1 and 2). The mitogenic stimulus used to evaluate the IL-12p70 and TNF- $\alpha$ dosage is rich in immunostimulating compounds such as peptidoglycans and lipoteic acid, being used to stimulate the macrophage functions in culture. ${ }^{76}$ Macrophages are fundamental cells in the immune response, as they immediately respond to stimuli mediated by their surface receptors and are important IL-12 and TNF- $\alpha$ 
sources in the innate immune response. ${ }^{74}$ In fact, several natural products are capable of modulating macrophage activity by interacting with molecular pattern receptors; in this sense, Orsatti et al..$^{77}$ and Pannacci et al. ${ }^{78}$ demonstrated an increase in TLR4 in peritoneal macrophages of animals treated with propolis and ginseng.

Thus, the immunomodulatory activity of the methanolic extract obtained from the $R$. marina poison seems to be the main target for macrophages, favoring IL-12p70 basal production at 7 days of treatment $\left(8 \mu \mathrm{g} \mathrm{mL} \mathrm{L}^{-1}\right.$ dose $)$ and TNF- $\alpha$ basal production at 30 days of treatment $\left(32 \mu \mathrm{g} \mathrm{mL}{ }^{-1}\right.$ dose).

The systemic changes observed in the animals during the evaluated experimental period do not seem to have affected the specific immune response, since we did not observe any difference in the lymphocyte proliferation or in the IL-4 and IL-10 production. In addition, an evaluation of other cytokines such as IL-8, IL-6, IL-1 $\beta$, IL-2 and IFN- $\gamma$ would be important to understand the effect of the extract on the immune response of mice.

The modulating effect on the immune system by compounds present in toad poison has already been observed by Carvalho et al. ${ }^{79}$ In this work, a study was carried out with the marinobufagin steroid and compared it to other steroids which have proven immunomodulatory activity. They showed the immunomodulatory activity of marinobufagin, with the steroid being able to negatively modulate inflammatory response parameters in a zymosaninduced peritonitis model such as polymorphonuclear leukocyte migration, IL-1 $\beta$ and IL-6 pro-inflammatory cytokines and NO production. However, marinobufagin did not interfere with mononuclear leukocyte migration or TNF- $\alpha$ production in an in vivo model, nor the cell viability of macrophages in culture. ${ }^{79}$

The pro-inflammatory effects of crude R. marina poison were also observed by Medeiros et al. ${ }^{49}$ Their results showed an important cellular influx after intraperitoneal injection of $R$. marina crude extract in mice, mainly composed by polymorphonuclear cells, and the ability to activate these cells for phagocytose and $\mathrm{O}_{2} \cdot$ production. $^{49}$

In fact, the studies by Medeiros et al. ${ }^{49}$ and Carvalho et al..$^{79}$ corroborate the pro-inflammatory action observed in our extract. This action was also evidenced by the increase in GSH levels observed in the treated mice.

Thus, it is possible that the pro- or anti-inflammatory action of R. marina extract may be a consequence of different intracellular signaling pathways triggered in macrophages, for example, by different conformational changes in $\mathrm{NA}^{+} / \mathrm{K}^{+}$-ATPase enzyme resulting in the activation of different transcription factors, such as the nuclear factor $(\mathrm{NF})$-kappa $(\kappa) \mathrm{B}$, or by the interaction with different molecular pattern receptors, such as TLR. ${ }^{79,80}$ Therefore, a molecular analysis of molecular pattern receptor expression and the involved intracellular signaling pathways in macrophages will also be important to understand the effect of the extract on the immune response of mice.

Furthermore, it is possible that chronic treatment for more than 30 days could induce more evident damage and enable better differentiation of the mechanisms associated with the action on the immune system. This is a preliminary study and despite presenting extract effects on cytokine production, the treatment showed toxic effects in the evaluated organs. In this sense, it is interesting to conduct new studies to investigate the effects of prolonged treatment with the extract, as well as to establish its therapeutic window and the interaction of its compounds with the receptors present in the macrophage.

\section{Conclusions}

It is possible to detect 15 compounds in studying the chemical profile of $R$. marina poison extract, with the compounds having the highest concentrations being divided into four classes: indolic alkaloid, derived argininyls, cardioactive steroids and steroidal compounds linked to argininyls. In this first study, the oxidative stress parameter results only demonstrated differences between doses, which does not enable confirming the antioxidant effect. The extract was able to modulate the cytokine production in the treated animals, and this effect may be related to tissue damage observed microscopically. These results are quite positive, since they demonstrate that the molecules present in the methanolic extract from $R$. marina poison have biotechnological potential, thus validating the hypothesis that poisons from these amphibians are rich sources of bioactive compounds. Further studies are needed to advance knowledge of these molecules in order to explore their mechanisms of action and to further contribute to Brazilian anurofauna knowledge.

\section{Acknowledgments}

This study was partly financed by the Coordenação de Aperfeiçoamento de Pessoal de Nível Superior Brazil (CAPES) - Finance Code 001. Acknowledgment PROPeq/ PROPG-UFMT for the financial support for publication.

\section{Author Contributions}

Sheila R. N. Pelissari was responsible for resources; Valéria D. G. Sinhorin for validation, writing-review and editing; Eloana B. R. de Souza for resources; Lindsey Castoldi for investigation; Leonardo G. de Vasconcelos 
for data curation; Domingos J. Rodrigues for funding acquisition; Jacqueline Kerkhoff for resources; Adilson P. Sinhorin for project administration, writing-review and editing.

\section{References}

1. Lewinsohn, T. M.; Prado, P. I.; Biodiversidade Brasileira: Síntese do Estado Atual do Conhecimento; Editora Contexto: Brasília, Brazil, 2002.

2. Pinto, A. C.; Silva, D. H. S.; Bolzani, V. S.; Lopes, N. P.; Epifanio, R. A.; Quim. Nova 2002, 25, 45.

3. Coe, M. T.; Marthews, T. R.; Costa, M. H.; Galbraith, D. R.; Greenglass, N. L.; Imbuzeiro, H. M.; Wang, J.; Philos. Trans. R. Soc., B 2013, 368, 20120155.

4. Santos, C. J. C.; Artigos Estratégicos 2016, 1, 89, available at http://www.ebrevistas.eb.mil.br/index.php/CEEExArE/article/ view/1197, accessed in April 2021.

5. Frost, D. R.; Amphibian Species of the World: An Online Reference; American Museum of Natural History (version 6.0): New York, USA, available at http://research.amnh.org/ herpetology/amphibia, accessed in April 2021.

6. AmphibiaWeb, Information on Amphibian Biology and Conservation; Berkeley, USA, 2019, available at https:// amphibiaweb.org/, accessed in April 2021.

7. Garcia, I. J. P.; Olivera, G. C.; Valadares, J. M. M.; Banfi, F. F.; Andrade, S. N.; Freitas, T. R.; Filho, E. S. M.; Santos, H. L.; Junior, G. M. V.; Chaves, M. H.; Rodrigues, D. J.; Sanchez, B. A. M.; Varotti, F. P.; Barbosa, L. A.; Steroids 2019, 152.

8. Cunha-Filho, G. A.; Resck, I. S.; Cavalcanti, B. C.; Pessoa, C. O.; Moraes, M. O.; Ferreira, J. R.; Rodrigues, F. A.; dos Santos, M. L.; Toxicon 2010, 56, 339.

9. Grant, T.; Toxicon 2019, 168, S1.

10. Jared, C.; Antoniazzi, M. M.; Jordão, A. E. C.; Silva, J. R. M. C.; Greven, H.; Rodrigues, M. T.; Toxicon 2009, 54, 197.

11. Sciani, J. M.; Angeli, C. B.; Antoniazzi, M. M.; Jared, C.; Pimenta, D. C.; Sci. World J. 2013, 2013, 937407.

12. Newman, D. J.; Cragg, G. M.; Snader, K. M. J.; Nat. Prod. 2020, 83,770 .

13. Cunha-Filho, G. A.; Schwartz, C. A.; Resck, I. S.; Murta, M. M.; Lemos, S. S.; Castro, M. S.; Kyaw, C.; Pires Jr., O. P.; Leite, J. R. S.; Bloch Jr., C.; Schwartz, E. F.; Toxicon 2005, 45, 777.

14. Ferreira, P. M. P.; Lima, D. J. B.; Debiasi, B. W.; Soares, B. M.; Machado, K. C.; Noronha, J. C.; Rodrigues, D. J.; Sinhorin, A. P.; Pessoa, C.; Vieira-Junior, G. M.; Toxicon 2013, 72, 43.

15. Schmeda-Hirschmann, G.; Quispe, C.; Theoduloz, C.; SousaJúnior, P. T.; Parizotto, C.; J. Ethnopharmacol. 2014, 155, $1076 \mathrm{e} 1085$.

16. Banfi, F. F.; Guedes, K. E. S.; Andrighetti, C. R.; Aguiar, A. C.; Debiasi, B. W.; Noronha, J. A. C.; Rodrigues, D. J.; Júnior, G. M.; Sanchez, B. A.; Korean J. Parasitol. 2016, 54, 415.
17. Lima, F. O.; Bezerra, A. S.; Disc. Scientia 2012, 13, 111.

18. Lambeth, J. D.; Neish, A. S.; Annu. Rev. Pathol.: Mech. Dis. 2014, 9, 119.

19. Martelli, F.; Nunes, F. M. F.; Cienc. Cult. 2014, 66, 54.

20. Zimmermann, A. M.; Kirsten, V. R.; Disc. Scientia 2008, 9, 51.

21. Carocho, M.; Ferreira, I. C. F. R.; Food Chem. Toxicol. 2013 , 51,15 .

22. Leonarduzzi, G.; Sottero, B.; Poli, G.; Food Chem. Toxicol. 2010, 128, 336.

23. Wiernsperger, N. F.; Diabetes Metab. 2003, 29, 579.

24. Barbosa, K. B. F.; Costa, N. M. B.; Alfenas, R. C. G.; Paula, S. O.; Minim, V. P. R.; Bressan, J.; Rev. Nutr. 2010, 23, 629.

25. Krinski, K.; Elsangedy, H. M.; Colombo, H. B.; Cosme, F.; Soares, I. A.; Campos, W.; Rev. Bras. Med. 2010, 67, 228.

26. Cruvinel, W. M.; Mesquita-Júnior, D.; Araújo, J. A. P.; Catelan, T. T. T.; Souza, A. W. S.; Silva, N. P.; Andrade, L. E. C.; Rev. Bras. Reumatol. 2010, 50, 434.

27. Gaur, K.; Kori, M. L.; Nema, R. K.; Global J. Pharmacol. 2009 , 3,85 .

28. Boscolo, O. H.; Mendonça-Filho, R. F. W.; Menezes, F. S.; Senna-Valle, L.; Rev. Bras. Plant. Med. 2007, 9, 8.

29. Nunes-Pinheiro, D. C. S.; Leite, A. K. R. M.; Farias, V. M.; Braga, L. T.; Lopes, C. A. P.; Ciência Animal 2003, 13, 23.

30. Costa-Lotufo, L. V.; Montenegro, R. C.; Alves, A. P. N. N.; Madeira, S. V. F.; Pessoa, C.; Moraes, M. E. A.; Moraes, M. O.; Rev. Virtual Quim. 2010, 2, 47.

31. Haddad, C. F. B.; Giovanelli, J. G. R.; Alexandrino, J. In A Biologia e as Mudanças Climáticas no Brasil; Buckeridge, M. S., ed.; RiMa Editora: São Carlos, Brazil, 2008.

32. Kerkhoff, J.; Noronha, J. C.; Bonfilio, R.; Sinhorin, A. P.; Rodrigues, D. J.; Chaves, M. H.; Junior, G. M. V.; Toxicon 2016, 119, 311; Sinhorin, A. P.; Kerkhoff, J.; Dall'Oglio, E. L.; Rodrigues, D. J.; Vasconcelos, L. G.; Sinhorin, V. D. G.; Toxicon 2020, 182, 30.

33. Oliveira, A. F.; Castoldi, L.; Vieira Jr., G. M.; Monção Filho, E. S.; Chaves, M. H.; Rodriques, D. J.; Sugui, M. M.; Acta Amazonica 2019, 49, 145.

34. Duan, W.; Chan, J. H.; Wong, C. H.; Leung, B. P.; Wong, W. S.; J. Immunol. 2004, 172, 7053.

35. Habig, W. H.; Pabst, M. J.; Jakoby, W. B.; J. Biol. Chem. 1974, 249,7130 .

36. Nelson, D. P.; Kiesow, L. A.; Anal. Biochem. 1972, 49, 474.

37. Sedlack, J.; Lindsay, R. H.; Anal. Biochem. 1968, 25, 192.

38. Buege, J. A.; Aust, S. D.; Methods Enzymol. 1978, 52, 302.

39. Bradford, M. M.; Anal. Biochem. 1976, 72, 248.

40. Pick, E.; Mizel, D.; J. Immunol. Methods 1981, 46, 211.

41. Green, L. C.; de Luzuriaga, K. R.; Wagner, D. A.; Rand, W.; Istfan, N.; Young, V. R.; Tannenbaum, S. R.; Proc. Natl. Acad. Sci. U. S. A. 1981, 78, 7764.

42. Gao, H.; Zehl, M.; Leitner, A.; Wu, X.; Wang, Z.; Kopp, B.; J. Ethnopharmacol. 2010, 131, 368. 
43. Schmeda-Hirschmann, G.; Quispe, C.; Arana, G. V.; Theoduloz, C.; Urra, F. A.; Cárdenas, C.; Toxicon 2016, 121, 119.

44. Petroselli, G.; Raices, M.; Jungblut, L. D.; Pozzi, A. G.; ErraBalsells, R.; J. Mass Spectrom. 2018, 53, 465.

45. Schmeda-Hirschmann, G.; Gomez, C. V.; Arias, A. R.; BurgosEdwards, A.; Alfonso, J.; Rolon, M.; Brusquetti, F.; Netto, F., Urra, F. A.; Cárdenas, C.; J. Ethnopharmacol. 2017, 199, 106.

46. Qi, J.; Zulfiker, A. H. M.; Li, C.; Good, D.; Wei, M. Q.; Nat. Commun. 2018, 9, 2282.

47. Yoshika, M.; Komiyama, Y.; Konishi, M.; Akizawa, T.; Kobayashi, T.; Date, M.; Kobatake, S.; Masuda, M.; Masaki, H.; Takashi, H.; Hypertension 2007, 49, 209.

48. Meng, Q.; Yau, L.-F.; Lu, J.-G.; Wu, Z.-Z.; Zhang, B.-X.; Wang, J.-R.; Jiang, Z. H.; J. Ethnopharmacol. 2016. 187, 74.

49. Medeiros, D. S.; Rego, T. B.; dos Santos, A. P. A.; Pontes, A. S.; Moreira-Dill, L. S.; Matos, N. B.; Zuliani, J. P.; Stábeli, R. G.; Teles, C. B. G.; Soares, A. M.; Sperotto, A. R. M.; Moura, D. J.; Saffi, J.; Caldeira, C. A. S.; Pimenta, D. C.; Calderon, L. A.; BioMed Res. Int. 2019, 2019, 2492315.

50. Tang, N.; Shi, L.; Yu, Z.; Dong, P.; Wang, C.; Huo, X.; Zhang, B.; Huang, S.; Deng, S.; Liu, K.; Ma, T.; Wang, X.; Wu, L.; Ma, X.-C.; Oncotarget 2016, 7, 3533.

51. Machado, K. C.; Sousa, L. Q.; Lima, M. J. B.; Soares, B. M.; Cavalcanti, B. C.; Maranhão, S. S.; Noronha, J. C.; Rodrigues, D. J.; Militão, G. C. G.; Chaves, M. H.; Vieira-Júnior, G. M.; Pessoa, C.; Moraes, M. O.; Sousa, J. M. C.; Melo-Cavalcante, A. A. C.; Ferreira, P. M. P.; Toxicol. Lett. 2018, 285, 121.

52. Tempone, A. G.; Pimenta, D. C.; Lebrun, I.; Sartorelli, P.; Taniwaki, N. N.; Andrade Jr., H. F.; Antoniazzi, M. M.; Jared, C.; Toxicon 2008, 52, 13.

53. Schmeda-Hirschmann, G.; de Andrade, J. P.; Soto-Vasquez, M. R.; Alvarado-García, P. A. A.; Palominos, C.; Fuentes-Retamal, S.; Mellado, M.; Correa, P.; Urra, F. A.; Toxins 2020, 12, 608.

54. Gowda, R. M.; Cohen, R. A.; Khan, I. A.; Heart 2003, 89, 431.

55. Pires, O. C.; Taquemasa, A. V. C.; Akisue, G.; Oliveira, F. O.; Araújo, C. E. P.; Acta Farm. Bonaerense 2004, 23, 176.

56. Banfi, F. F.; Krombauer, G. C.; Fonseca, A. L.; Nunes, R. R.; Andrade, S. N.; Rezende, M. A.; Chaves, M. H.; Filho, E. S. M.; Taranto, A. G.; Rodrigues, D. J.; Júnior, G. M. V.; Castro, W. V.; Varotti, F. P.; Sanchez, B. A. M.; J. J. Venomous Anim. Toxins Incl. Trop. Dis. 2021, 27, 1.

57. Aizarani, N.; Saviano, A.; Sagar; Mailly, L.; Durand, S.; Herman, J. S.; Pessaux, P.; Baumert, T. F.; Grün, D.; Nature 2019, 572, 199.

58. Fernández-Sánchez, A.; Madrigal-Santillán, E.; Bautista, M.; Esquivel-Soto, J.; Morales-González, Á.; Esquivel-Chirino, C.; Durante-Montiel, I.; Sánchez-Rivera, G.; Valadez-Veja, C.; Morales-González, J. A.; Int. J. Mol. Sci. 2011, 12, 3117.
59. Gebicka, L.; Krych-Madej, J.; J. Inorg. Biochem. 2019, 197, 110699.

60. Saha, D.; Av. Biomed. 2014, 3, 84.

61. Pereira, D. L.; Cunha, A. P. S.; Cardoso, C. R. P.; Rocha, C. Q.; Vilegas, W.; Sinhorin, A. P.; Sinhorin, V. D. G.; Acta Amazonica 2018, 48, 347.

62. Berno, L. I.; Poeta, P. T.; Maróstica Jr., M. R.; Aliment. Nutr. 2010, 21, 231.

63. Samudrala, P. K.; Augustine, B. B.; Kasala, E. R.; Bodduluru, L. N.; Barua, C.; Lahkar, M.; Pharmacogn. Res. 2015, 7, 66.

64. Li, Z.; Zlabek, V.; Velisek, J.; Grabic, R.; Machova, J.; Randak, T.; Comp. Biochem. Physiol. 2010, 151, 137.

65. Dobashi, K.; Aihara, M.; Araki, T.; Shimnizu, Y.; Utsugui, M.; Ilzura, K.; Murata, Y.; Hamuro, J.; Nakazawa, T.; Mori, M.; Clin. Exp. Immunol. 2001, 124, 290.

66. Fraternale, A.; Brundu, S.; Magnami, M.; Biol. Chem. 2017, 398, 261.

67. Chatterjee, P.; Chiasson, V. L.; Bounds, K. R.; Mitchell, B. M.; Front Immunol. 2014, 5, 253.

68. Gregory, G. D.; Raju, S. S.; Winandy, S.; Brown, M. A.; J. Clin. Invest. 2006, 116, 1327.

69. Oliveira, C. B.; Sakata, R. K.; Issy, A. M.; Gerola, L. R.; Salomão, R.; Rev. Bras. Anestesiol. 2011, 61, 255.

70. Wang, S.; Wang, J.; Ma, R.; Yang, S.; Fan, T.; Cao, J.; Zhang, H.; Mol. Immunol. 2020, 121, 92.

71. Lawrence, T. C.; Flores, J. V. F.; Costa-Carvalho, B. T.; Rev. Bras. Alergia Imunopatol. 2006, 29, 167.

72. Holland, S. M.; Microbes Infect. 2000, 2, 1579.

73. Santos, P. P. A.; Freitas, V. S.; Freitas, R. A.; Pinto, L. P.; Souza, L. B.; Odontol. Clín.-Cient., Recife 2010, 9, 215.

74. Abbas, A. K.; Lichtman, A. H.; Pillai, S.; Imunologia Celular e Molecular; Elsevier: Rio de Janeiro, Brazil, 2015.

75. Trinchieri, G.; Nat. Rev. 2003, 3, 133.

76. Zhu, F. G.; Pisetsky, D. S.; Immunology 2001, 103, 226.

77. Orsatti, C. L.; Missima, F.; Pagliarone, A. C.; Bachiega, T. F.; Búfalo, M. C.; Araújo, J. P.; Forcin, J. M.; Phytother. Res. 2010, 24, 1141.

78. Pannacci, M.; Lucini, V.; Colleoni, F.; Martucci, C.; Grosso, S.; Sacerdote, P.; Scaglione, F.; Brain, Behav., Immun. 2006, 20, 546.

79. Carvalho, D. C. M.; Cavalcante-Silva, L. H. A.; Lima, E.; Galvão, J. G.; Alves, A. K. A.; Feijó, P. R. O.; Quintas, L. E. M.; Rodrigues-Mascarenhas, S.; J. Immunol. Res. 2019, 1094520.

80. Md. Zulfiker, A. H.; Hashimi, S. M.; Qi, J.; Grice D.; Wei, M. Q.; J. Cell. Biochem. 2016, 117, 2769.

Submitted: November 5, 2020 Published online: April 20, 2021 